\title{
FIRE PROTECTION OF WOODEN STORAGE CONTAINERS FOR EXPLOSIVE AND PYROTECHNIC PRODUCTS
}

\author{
Sergii Guzii \\ V. D. Glukhovsky Scientific Research Institute of Binders and \\ Materials Department of technology of building designs and products \\ Kyiv National University of Construction and Architecture \\ 31 Povitroflotskii av., Kyiv, Ukraine, 03680 \\ sguziy@ukr.net \\ Yurii Tsapko \\ V. D. Glukhovsky Scientific Research Institute of Binders and \\ Materials Department of technology of building designs and products \\ Kyiv National University of Construction and Architecture \\ 31 Povitroflotskii av., Kyiv, Ukraine, 03680 \\ juriyts@ukr.net \\ Anastasiya Kravchenko \\ V. D. Glukhovsky Scientific Research Institute of Binders and \\ Materials Department of technology of building designs and products \\ Kyiv National University of Construction and Architecture \\ 31 Povitroflotskii av., Kyiv, Ukraine, 03680 \\ krav.anastasiya@gmail.com \\ Myhailo Remenets \\ LLC «Engineering Center «Signal» \\ 8 Ivan Lepse blvd., Kyiv, Ukraine, 03067 \\ mir1@ukr.net
}

\begin{abstract}
Analysis of the emergency storage facilities for explosive and pyrotechnic products is conducted. It is established that one of the greatest risks is their flammability. Since the explosive and pyrotechnic products are stored in wooden containers, there is a need for their fire protection. To determine the efficiency of fire resistant containers for packaging explosive products it is designed operating range of testing method. This method is necessary to establish mass loss, measuring the growth temperature and response time of the squibs. The results of the efficiency of the fire retardant treatment of wood and organic coated coating showed that when exposed to high-temperature destruction of the cone struction detonation of the squibs didn't happen.

Tests to determine the quality of the fire retardant treatment of wood coatings showed that the temperature on the inner surfaces of the untreated sample was more than $760{ }^{\circ} \mathrm{C}$, samples with fire retardant coatings - no more than $128^{\circ} \mathrm{C}$. The conclusion of the feasibility of using fire - retardants is not based on inorganic and organic binders for the treatment of wooden structures.

Method of determining the fire protection is used to assess the efficiency of the fire protection of wooden structures. Method comprises determining the ratio of the sample rate of burnout, the temperature increment and the ignition time of untreated and treated samples. As a result of the firing testing it is established a speed burnout reduction of samples of the container with treated coatings compared with untreated coatings is decreased by 2,4-4,4 times and respectively fire protection efficiency factor of treated samples of the container compared to untreated is increased by $1.8-4.1$ times.
\end{abstract}

Keywords: wooden containers, fire retardant coatings, concrete, methodology, inorganic and organic coatings.

(C) Sergii Guzii, Yurii Tsapko, Anastasiya Kravchenko, Myhailo Remenets

\section{Introduction}

Emergency at the sites of storage of explosive products that may occur on the territory of Ukraine and negatively affect the ability to live in peace, are distributed according to the following features: 
- area of origin;

- appurtenance;

- scale of the possible consequences.

According to the first feature, emergencies at the sites of storage of explosive products can be classified by the nature of occurrence on the natural and technogenic. Natural emergencies can classify by the types of possible natural events that lead to their occurrence: geological, meteorological, natural fires, soil degradation, and others.

According to the second feature, emergencies are dived into those that can arise in the buildings in the industrial production, during storage, during transportation of explosive products. Technogenic emergencies are classified according to the characteristics of the phenomena that define the features of the actions of people defeat the factors of the environment and objects of managing. There are accidents, which are accompanied by fires, explosions, emissions of hazardous substances, destruction of buildings and structures (including under the influence of incendiary) and other factors.

According to the third feature, emergencies at the arsenals, bases and storage warehouses for weapons and ammunition lead to the complete destruction of the object causing considerable damage to the environment paralyzing the infrastructure of settlements and form a threat to the civilian population.

One of the most significant risk factors for the storage objects with explosive goods is their flammability. Vitality in the normal conditions and in emergency is depended from the choice of providing the fire protection systems of such objects. Therefore, the problem associated with the use of combustible materials (wood, plywood and paper products) in building construction and packaging products has become even more urgent and found a low level of safety of operation of such objects. Given that the basic material for the manufacture of packaging is wood and its modifications (plywood, fibreboard) that by flammability group are belong to the combustible materials of medium flammability, it must have fire retardant treatment. The essence of the fire retardant treatment of wood is providing the ability to resist flame effect; the flame spread on the surface to prevent the free access of oxygen, which contributes to the destruction of wood and acceleration of the combustion process, can significantly affect or eliminate the occurrence of fire [1-5].

As an alternative solution to the problem of fire protection of wooden structures is possible to use the retardant composition on the base of geocement. Geocements (TU U V.2.7-16403272.001-97, Ukraine) are a kind of alkali cements, which are environmentally friendly and characterized by high durability due to the synthesis of the structure of substances, analogues of natural zeolites and feldspathoidal. Geocements are fire- and heat-resistant, characterized by low elasticity, under the influence of the temperature factor emit in the environment only water vapour, but require application to the building structure of considerable thickness of the protective layer [6-15].

Efficiency improvement of a fire retardant coating is possible due to the formation of coke-expanded layer. Coke layer on the surface of the construction significantly reduces the heat transfer process to a substrate material [16-19].

The aim is to develop techniques and methods for determining the efficiency of fire resistant containers for packaging explosive products treated with fire retardant coating on the organic-mineral and mineral bases.

Based on this aim, model samples of wooden containers for storage of hazardous products with thickness of $19 \mathrm{~mm}$ were tested:

a) untreated (sample № 1: Fig. 1);

b) fire retardant samples - samples of the container have been treated with fire retardant coatings:

- fire retardant inorganic-based coating (utility model patent of Ukraine № 95440 "Fire retardant coating for wood”, sample № 2: Fig. 2);

- fire retardant organic and mineral-based coating (experimental sample № 3: Fig. 3);

- fire retardant geocement coating with a heat-reflective screen (experimental sample № 4: Fig. 4).

Incendiary mixture ("napalm" model) was used as a sample of the liquid fuel.

Thermocouples, which are attached to the measuring unit, were mounted on the sample of the containers. Mixture fuel per rate of $50 \mathrm{ml}$ on $1 \mathrm{dm}^{2}$ was set on the lid and the side walls of the sample. 

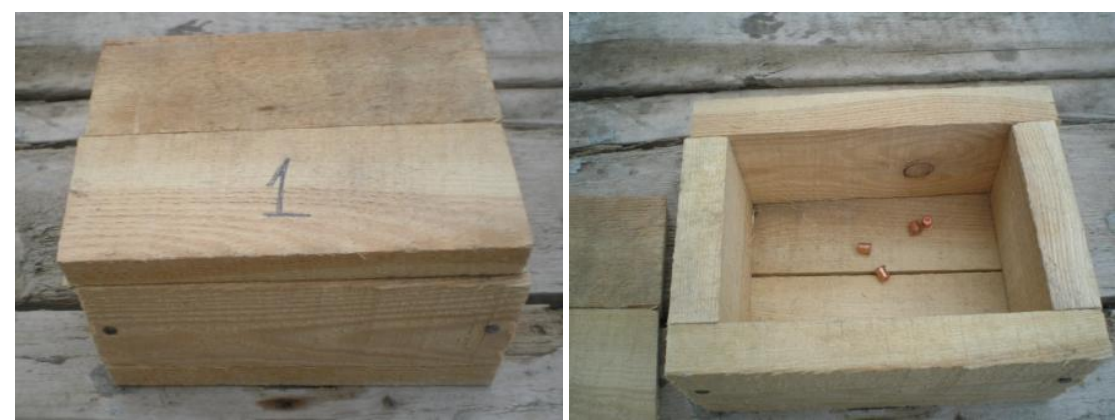

Fig. 1. Untreated model sample of the containers for storage of ammunition

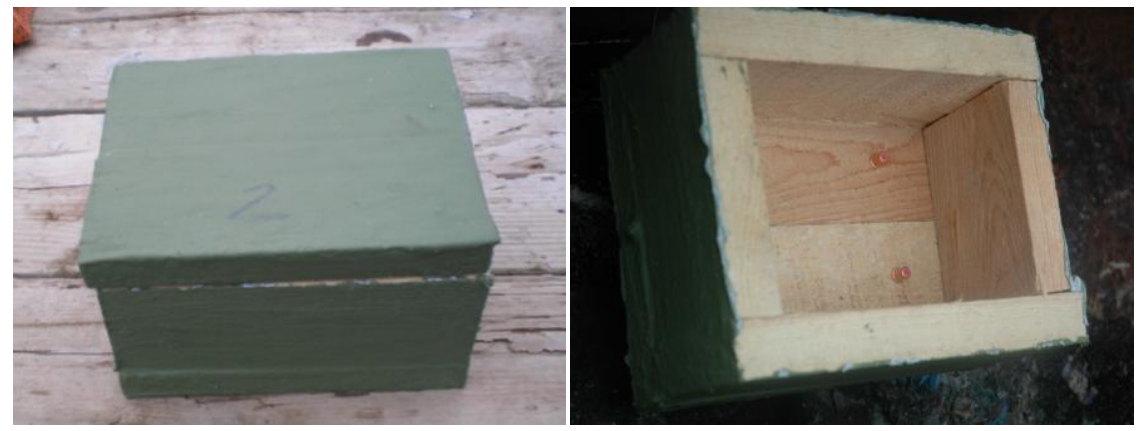

Fig. 2. Fire resistant model sample of the containers for storage of ammunition, which is treated with a fire retardant coating (utility model patent of Ukraine № 95440)
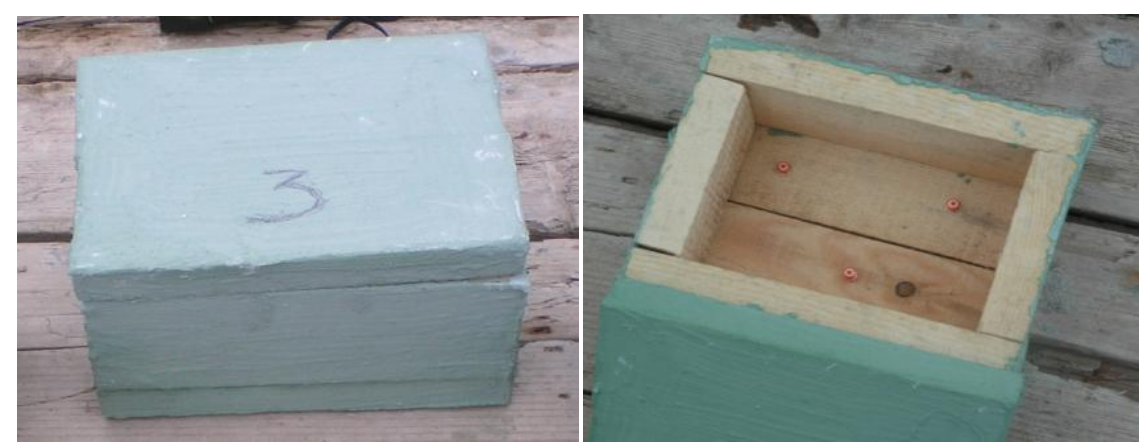

Fig. 3. Fire resistant model sample of the containers for storage of ammunition, which is treated with organic-mineral fire retardant coating

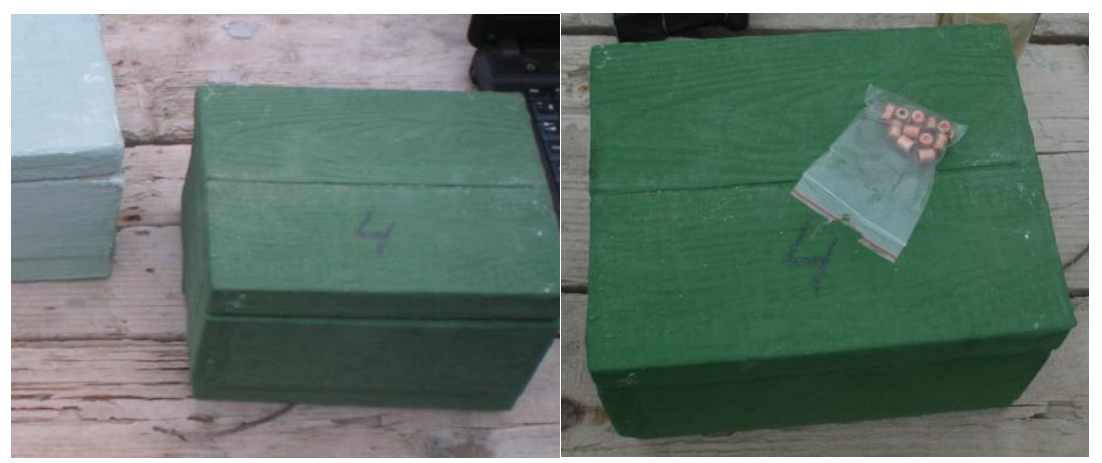

Fig. 4. Fire resistant model sample of the containers for storage of ammunition, which is treated with geocement coating with heat-reflecting screen 
Sample was kept in wooden containers for a time before the lack of self-combustion and smolder to control the temperature on the inner surfaces of the container and the response time for detonation of the squibs. Mass loss of the sample after thermal exposure was determined.

Tests to determine the efficiency of fire resistant containers for storage of ammunition were conducted under the following conditions:

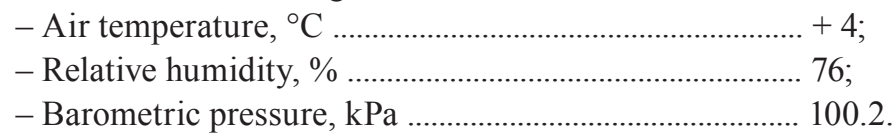

\section{Methods}

To develop techniques and methods for determining the efficiency of fire resistant containers for storage of explosive products treated with fire retardant organic-mineral- and inorganic-based coatings, the following methods were used:

- visual that allows determining the appearance of the material and its damage after a fire attack;

- mass weight that allows determining the mass loss of sample after fire test;

- temperature-time that allows determining the temperature on the inner walls of wooden products with the help of analog-to-digital converter ADAM and time to detonation of the squibs;

- rate of burning the samples was determined at term stand OTM and KT (GOST 12.1.044, GOST 16363-98, Ukraine).

\section{Fire tests of fire resistant designs of wooden containers}

In the first stage, untreated sample of the container was tested, and in the subsequent stages wooden packaging samples of the container treated with fire retardant coating were tested. Below it is shown the kinetics of the temperature dependence on the inner surfaces of wooden containers from the test time: Fig. 5-12.

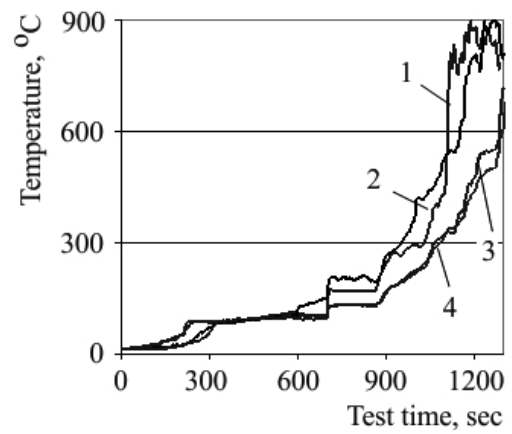

Fig. 5. Results of measuring temperature on the inner surfaces of untreated sample of the containers: 1 - bottom; 2, 3 - side wall; 4 - lid
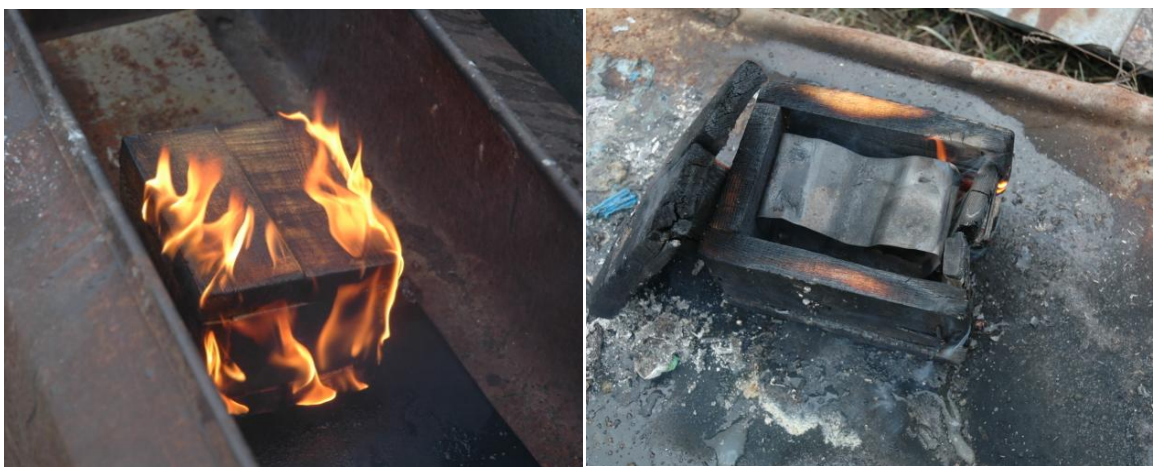

Fig. 6. Fire test results for untreated model sample of the containers for storage of weapons and ammunition 
Test results for untreated sample showed that: sample continued to burn after the fuel combustion to the loss of integrity, the maximum temperature reached $800{ }^{\circ} \mathrm{C}$, the squibs detonated after $900 \mathrm{sec}$ of thermal effect on the sample.

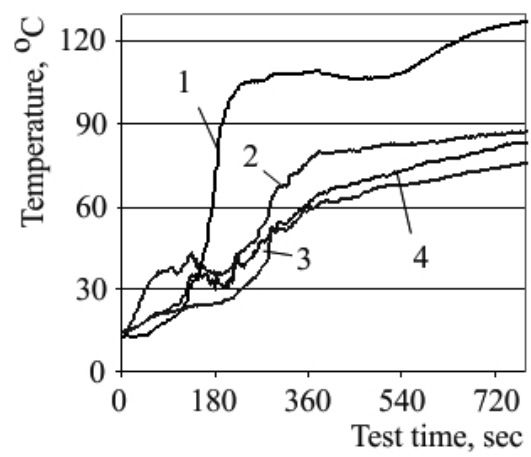

Fig. 7. Results of measuring temperature on the inner surfaces of sample of the container №2:

$$
1 \text { - bottom; 2, } 3 \text { - side wall; } 4 \text { - lid }
$$
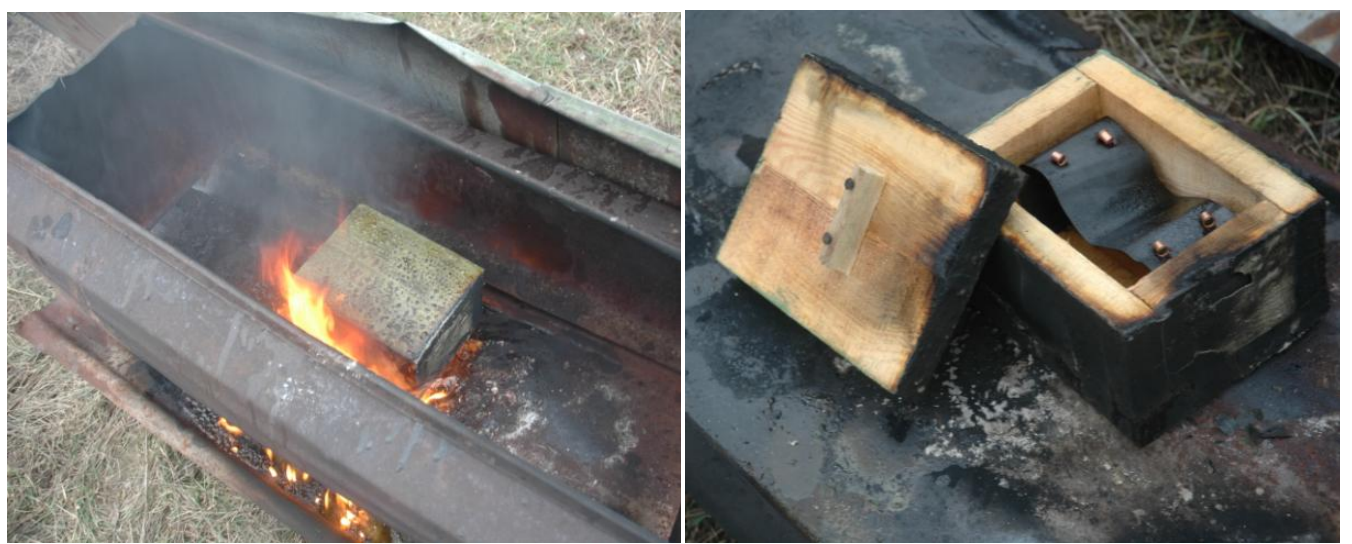

Fig. 8. Fire test results of model sample of the containers for storage of weapons and ammunition treated with fire retardant coating (utility model patent of Ukraine № 95440)

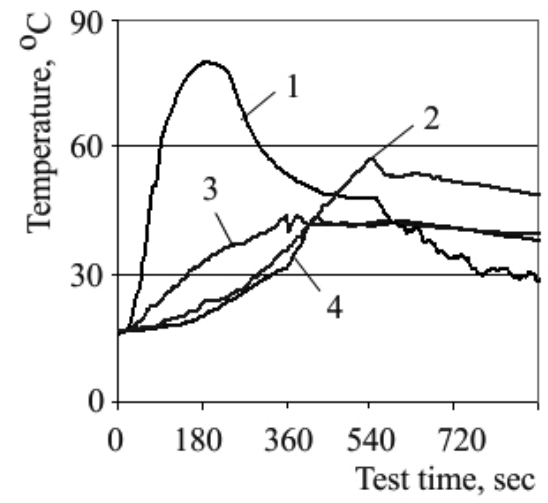

Fig. 9. Results of measuring temperature on the inner surfaces for sample of the container № 3:

$$
1 \text { - bottom; 2, } 3 \text { - side wall; } 4 \text { - lid }
$$

As a result of the fire tests it was found that for samples with application of fire retardant coatings is no burn-out of the bottom and the walls; the temperature on the inner walls didn't exceed $140{ }^{\circ} \mathrm{C}$, which is insufficient to detonation of the squibs.

The mass loss results and response time of the squibs are shown in the Table 1. 

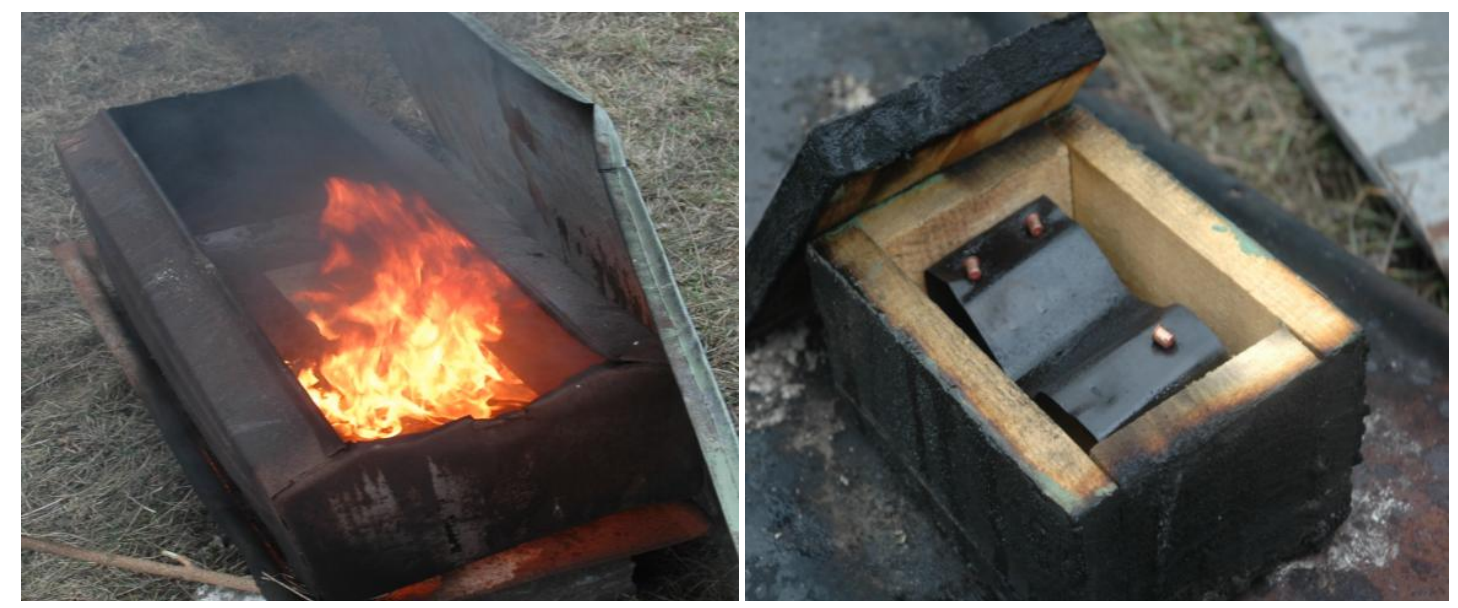

Fig. 10. Fire test results for model sample of the containers for storage of weapons and ammunition treated with organic-mineral protective coating

Table 1

Results of the mass loss of wooden containers and response time of the squibs

\begin{tabular}{|c|c|c|c|c|c|}
\hline \multirow{2}{*}{$\begin{array}{l}\text { Samples of the con- } \\
\text { tainer for testing }\end{array}$} & \multicolumn{2}{|c|}{ Weight of the container, $\mathrm{kg}$} & \multirow{2}{*}{$\begin{array}{l}\text { Ignition time, } \\
\text { sec }\end{array}$} & \multirow{2}{*}{$\begin{array}{l}\text { Response time of } \\
\text { the squibs, sec }\end{array}$} & \multirow{2}{*}{$\begin{array}{l}\text { Mass loss of the } \\
\text { sample D m, \% }\end{array}$} \\
\hline & before testing & after testing & & & \\
\hline №1 & 1.671 & 0.388 & 320 & 940 & 76.8 \\
\hline № 2 & 1.771 & 1.651 & - & - & 6.7 \\
\hline № 3 & 1.751 & 1.685 & - & - & 3.7 \\
\hline № 4 & 1.833 & 1.701 & - & - & 7.2 \\
\hline
\end{tabular}

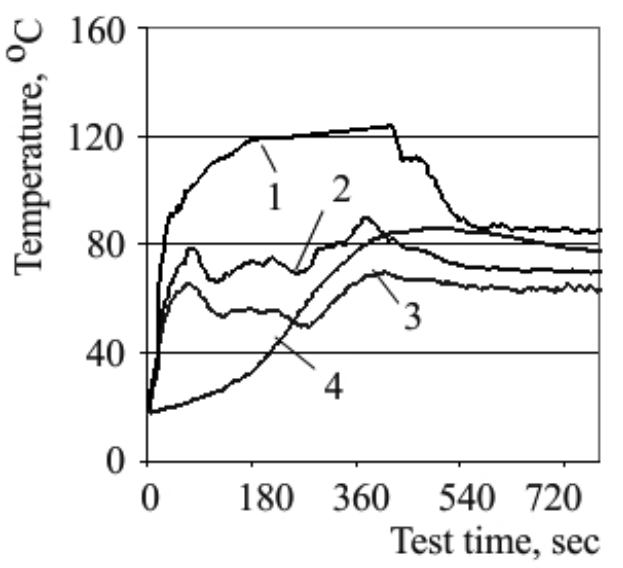

Fig. 11. Results of measuring temperature on the inner surfaces of sample of the container № 4:

1 - bottom; 2, 3 - side wall; 4 - lid

As a result of the fire tests it was established that:

- untreated model sample of the containers for storage of weapons and ammunition is capable for ignition and flame spread on the surface after the ignition of it by the model "napalm" mixture. This is lead to detonation of the squib and destruction of the sample;

- model sample of the container for storage of weapons and ammunition treated with retardant coating (utility model patent of Ukraine № 95440) after burning of model “napalm” mixture 
for $60 \mathrm{sec}$ continued to burn at the junction of the building structure. Destruction of the sample and detonation of the squibs didn't happen. Peeling and shedding the protective coating in some areas due to thermal effects of the flame was fixed;

- model sample of the containers for storage of weapons and ammunition treated with organic-mineral retardant coating after a burnout of the model "napalm" mixture was not burned. Destruction of the sample and detonation of the squibs didn't happen. Swelling of the protective coating in certain areas when exposed to flame, in particular in the bottom part of the container was not fixed;

- model sample of the container for storage of weapons and ammunition treated with geocement coating with a heat-reflective screen after burnout of the model "napalm" mixture for 60 seconds didn't burn. Destruction of the sample and detonation of the squibs didn't happen. Peeling and shedding the protective coating in some areas due to effects of the flame was fixed.
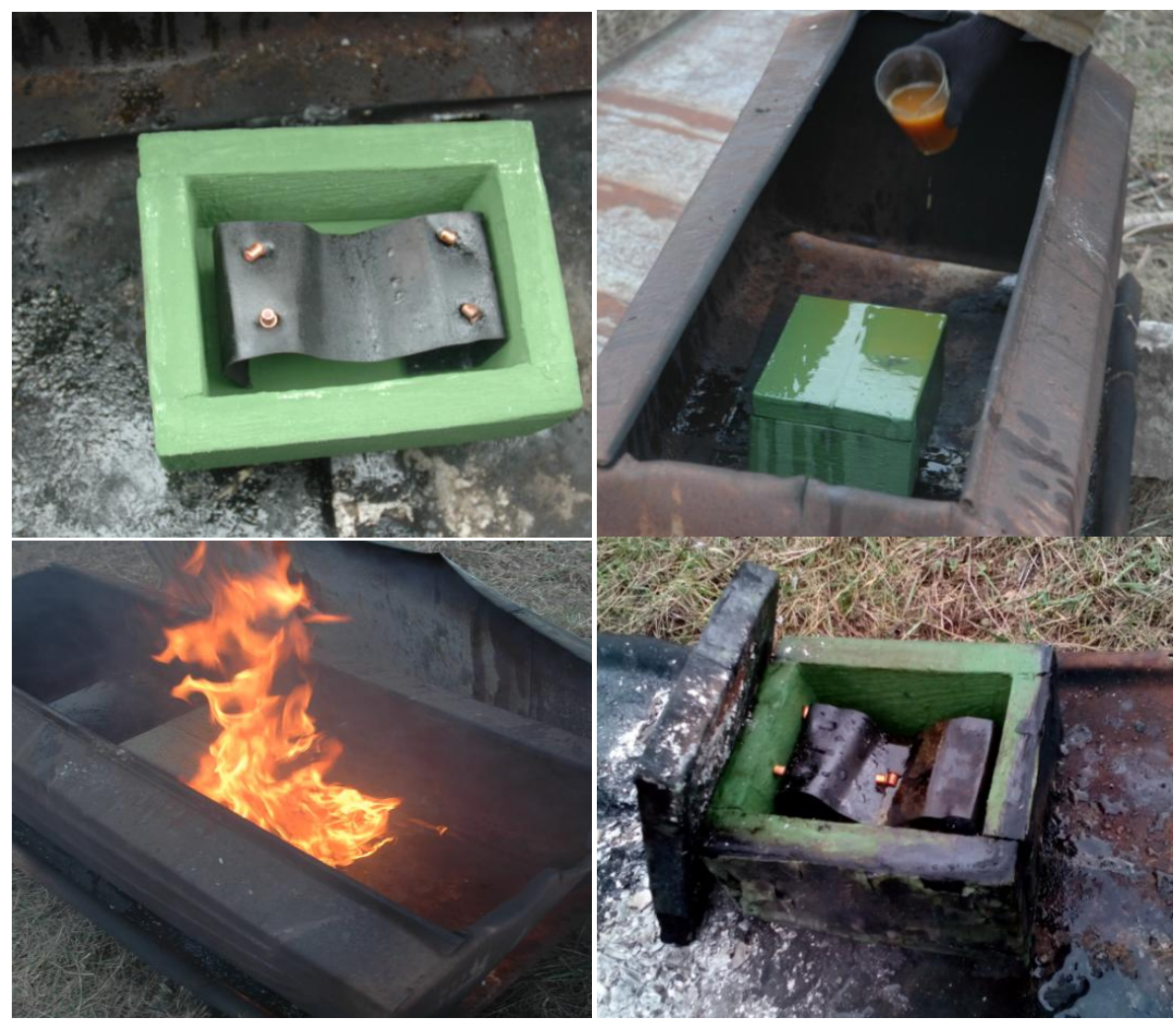

Fig. 12. Fire test results for model sample of the containers for storage of weapons and ammunition treated with geocement coating with heat-reflecting screen

\section{Providing a process for determining the efficiency of fire resistant containers for storage of explosive products}

Method of determining the fire protection efficiency is made for estimating the fire protection of the wooden container. According to the proposed method, fire protection efficiency is determined by the ratio of the mass burn rate of untreated and treated samples. The loss of mass of the sample and the area of damage after fire tests is calculated [20-24]. The temperature of the internal surfaces of container is measured. Combustion characteristics are evaluated after the flammability test according to the coefficient $\mathrm{E}_{\mathrm{T}}$ :

$$
\mathrm{E}_{\mathrm{T}}=\frac{v_{\mathrm{untr}}}{v_{\mathrm{tr}}} \cdot\left(1-\frac{\Delta \mathrm{T}_{\mathrm{untr}}}{\Delta \mathrm{T}_{\mathrm{tr}}}\right) \cdot\left(1-\frac{\tau_{\mathrm{untr}}}{\tau_{\mathrm{tr}}}\right),
$$

where: $\Delta \operatorname{Tuntr}=\operatorname{Tuntr}_{\text {os }}-\operatorname{Tuntr}_{\text {is }}-$ the difference between the maximum temperature on the outer $\left(\right.$ Tuntr $_{\text {os }}$ ) and internal ( Tuntr $_{\text {is }}$ ) surfaces of untreated sample of the container, respectively; 
$\Delta \mathrm{T}_{\mathrm{tr}}=\mathrm{Ttr}_{\mathrm{os}}-\mathrm{Ttr}_{\mathrm{is}}-$ the difference between the maximum temperature at the outer $\left(\mathrm{Ttr}_{\mathrm{os}}\right)$ and internal $\left(\mathrm{Ttr}_{\text {is }}\right)$ surfaces of treated sample of the container, respectively;

$\tau_{\text {untr }}$ - ignition time of untreated sample;

$\tau_{\mathrm{tr}}-$ ignition time of retardant sample;

$v_{\text {untr }}, v_{t r}$ - mass burning rate of untreated and treated samples, which is calculated according to the formula [2]:

$$
v_{\text {untr(tr) }}=\frac{\Delta \mathrm{m}}{\tau \cdot \mathrm{S}}
$$

where: $\Delta \mathrm{m}$ - mass loss of sample after testing, $\mathrm{kg}$;

$\tau-$ duration of test, $\mathrm{s}$;

$\mathrm{S}$ - damage area of sample, $\mathrm{m}^{2}$.

The results of calculation of the mass burning rate of the untreated and treated samples container for storage of the squibs: Table 2.

Table 2

The mass burning rate of untreated and treated samples of the wooden containers

\begin{tabular}{ccccc}
\hline $\begin{array}{c}\text { Samples of the container } \\
\text { for testing }\end{array}$ & $\begin{array}{c}\text { Mass loss of } \\
\text { sample, } \Delta \mathbf{~ m , ~ k g}\end{array}$ & $\begin{array}{c}\text { Test times, } \\
\text { sec }\end{array}$ & $\begin{array}{c}\text { Damage area of } \\
\text { sample S, } \mathbf{~ m}^{\mathbf{2}}\end{array}$ & $\begin{array}{c}\text { Burning rate of sample, } \\
\mathbf{k g} / \mathbf{s} \cdot \mathbf{m}^{\mathbf{2}}\end{array}$ \\
\hline № 1 & 1.283 & 1800 & 0.151 & 0.0049 \\
№ 2 & 0.120 & 1800 & 0.033 & 0.0020 \\
№ 3 & 0.066 & 1800 & 0.032 & 0.0011 \\
№ 4 & 0.132 & 1800 & 0.042 & 0.0017
\end{tabular}

It is established that the burning rate of sample of the container treated with fire retardant coatings decreases by 2.4-4.4 times over untreated. Calculated for (1) coefficients of fire protection efficiency (Em) for container during combustion are given in the Table 3.

Table 3

Coefficients of fire protection efficiency $\left(\mathrm{E}_{\mathrm{T}}\right)$

\begin{tabular}{cccc}
\hline $\begin{array}{c}\text { Samples of the } \\
\text { container for testing }\end{array}$ & $\begin{array}{c}\text { The maximum temperature } \\
\text { on the inner surfaces, }{ }^{\circ} \mathbf{C}\end{array}$ & $\begin{array}{c}\text { The maximum temperature on the } \\
\text { outer surface, }{ }^{\circ} \mathbf{C}\end{array}$ & $\begin{array}{c}\text { Coefficient of } \\
\text { efficiency, ET }\end{array}$ \\
\hline №1 & 760 & 960 & - \\
№ 2 & 128 & 958 & 1.86 \\
№ 3 & 84 & 960 & 3.43 \\
№ 4 & 122 & 960 & 2.19
\end{tabular}

As a result of the fire test and calculation it is established that the coefficient of fire protection efficiency of the container for treated samples increases by 1.8-4.1 times compared to untreated.

\section{Conclusions}

Thus, the use of the proposed methodology enables an experimental calculation method to determine the efficiency of fire protection of wooden storage and increase the accuracy of the assessment results.

References

[1] Zhartovsky, V. M., Tsapko, Y. V. (2006). Prevention of burning cellulose-containing materials. Theory and practice. Kiev: UkrNIIPB Emergencies of Ukraine, 256. 
[2] Zhartovsky, V. M., et al. (2004). Investigation of the mechanism of fireproof efficiency wood impregnating compositions. Utilities cities: scientific and technical collection, Vol. 55 (Engineering and Architecture). Kyiv, Technique.

[3] Tsapko, Y. V. (2006). Prospects for increasing the efficiency of the fire protection of cellulose materials. Proc. Sciences works. Vol. 8. Lviv, LSU Health and Safety.

[4] Zhartovsky, V. M., et al. (2006). Compliance modern impregnating agents multifactorial evaluation of the efficiency of fire protection timber. Utilities cities: Scientific and technical collection, Vol. 42 (Engineering and Architecture). Kyiv, Technique.

[5] Tsapko, Y. V. (2005). Determination of the efficiency of fire protection of cellulose materials. Proc. scientific works, Vol. 7. Lviv, LIPB.

[6] Krivenko, P. V., et al. (2009). Fireproof coatings on the basis of alkaline aluminum silicate systems. Developments in Strategic Materials: Ceramic Engineering and Science Proceedings, Vol. 29, Issue 10. doi: 10.1002 / $9780470456200 . \operatorname{ch} 13$

[7] Krivenko, P. V., Guzii S. G., Kravchenko, A. V. (2013). Protection of Timber from Combustion and Burning Using Alkaline Aluminosilicate-Based Coatings Advanced Materials Research, Vol. 688. doi:10.4028/www.scientific.net/AMR.688.3.

[8] Guzii, S. G., Kravchenko, A. V. (2013). Fire wood coating based on geocement. Sciences collection. Kyiv, IDUTSZ, № 1 .

[9] Gusii, S. G., Tsapko, Y. V. (2013). The study of some aspects of the impact on the stability of wood protection wood structures. Proc. $1^{\text {st }}$ International Conference on the Chemistry of Construction Material by the GDCh Division of Chemistry of Construction Chemicals, October 7-9, Berlin.

[10] Tsapko, Y. V., Guzii, S. G., Kravchenko, A. V. (2014). Investigation of fire-resistant properties of fire retardant wood coating based on geocement. Col. Resource materials, structures, buildings and facilities. Rivne, NUVHP. Vol. 29.

[11] Petránek, V., Guziy, S., Sotiriadis, K., Nevřivová, L. (2013). Study on the Properties of Geocement Based Thermal Insulating Materials for High Temperature Technical Appliances. Advanced Materials Research Vols. 734-737. doi:10.4028/www.scientific.net/AMR.734-737.2356.

[12] Krivenko, P. V., Guziy, S. G., (2013). Aluminosilicate coatings with enhanced heat-and corrosion resistance. Applied Clay Science. Vol. 73. Elsevier. doi: 10.1016 / j.clay.2012.10.010.

[13] Kravchenko, A. V., Guzii S. G., Tsapko, Y. V., Petranek, V., (2015). Advanced Materials Research. Vol. 1122. doi:10.4028/www.scientific.net/AMR.1122.7.

[14] Guzii, S. G., et al. (2015). Heat-reflecting Geocement Based Coatings Containing Perlite for Fire Protection of Timber. Advanced Materials Research. Vol. 1122. doi:10.4028/www.scientific.net/AMR.1122.11.

[15] Petránek, V., et al., (2014). New Thermal Insulating Material Based on Geocement. Advanced Materials Research Vols. 838-841. doi:10.4028/www.scientific.net/AMR.838-841.183.

[16] Tsapko, Y. V. et al. (2014). Fire resistance of Research and flame spread index on the surface of the protected coated wood-based geocement. Col. Building materials, products, and sanitary equipment. Kyiv, To Society "Knowledge" of Ukraine. Issue 52.

[17] Stakhov, V. L., Gerashchenko, A. M. (2002). Fire building constructions: modern means and methods of optimal design. J. Building materials. Moscow, Stroyizdat, № 6.

[18] Trofimova, O. N. (2013). Optimization of fire protection of metal constructions. J. Fire and explosion safety. Vol. 33. №1.

[19] Nenakhov, S. A., Pimonova, V. P., Pimenov, A. L. (2010). Problems retardant industry. J. Fire and explosion safety. Vol. 12. № 12.

[20] Pat. 60942 Ukraine, IPC V27K 3/08. The method of preparation / handling of wooden containers for storing hazardous products and ammunition, to ensure its vognebiostiykosti. [Moszkowski, M. S., Tsapko, Y. V., Berezovsky, A. I., et al.]; Stated. 22.03.2011; Publ. 25.06.2011; Bull. No 12.

[21] Tsapko, Y. V., et al. (2008). Increasing fire protection storage depots of arms and ammunition through the use of flame retardancy of wood. Techno Security. Theory, practice and innovation. Coll. abstract int. scientific and practical. Conf. St.-Petersburg.

[22] Tsapko, Y. V., (2008). Aspects of wood fire protection options for improving fire protection of weapons and ammunition storage depots. Coll. Sciences. Sevastopol Naval Institute. P. S. Nahimova. Vol. 1(14).

[23] Pat. 82592 Ukraine, IPC G01N25 / 18, C09K 21/00. The method for determining the efficiency of the flame-retardant solid sheet materials. [Barylo, O. G., Kharchenko I. O., Tsapko Y. V, et al.]; Stated. 28.07.2006; Publ. 25.04.2008; Bull. No 8.

[24] Pat. 37035 Ukraine, IPC G01N25 / 18. The method for determining the efficiency of fire protection of wooden containers for the storage of flammable and explosive goods. [Tsapko, Y. V., Zhartovsky, V. M., Bykov, A. V., et al.]; Stated. 26.06.2008; Publ. 10.11.2008; Bull. No 21. 